\title{
Loyalty program and its influence on customer loyalty on mobile service with customer satisfaction as a mediating variable
}

\author{
Mulyadi Raf ${ }^{1)}$, Agus Syarif ${ }^{2)}$ \\ ${ }^{1,2)}$ Fakultas Ekonomi Universitas Jambi, Jambi, Indonesia \\ Corresponding Author: mulyadi_raf@unja.ac.id
}

\begin{abstract}
This study aims to analyze 1) the influence of loyalty program benefits on customer satisfaction, 2) the influence of loyalty program on customer loyalty, 3. the influence customer satisfaction on customer loyalty, and 4) the role of customer satisfaction in mediating the relationships of customer loyalty program and customer loyalty to mobile service providers in Jambi City. To test the benefits between the constructs, a model was developed as a conceptual framework of the research. A total of 202 samples were collected from mobile user population in Jambi city. Structural Equation Modeling (SEM) with Smart PLS was applied to assess the research model and to test the hypothesis. The result confirmed that the influence of loyalty program benefits directly and significantly affect customer loyalty at coefficient path 0,237 ( $t$ statistics $=$ 2,669 < table 1, 96). Customer perceptions significantly affects customer satisfaction at coefficient path 0.625 ( $t$ statistical $=2,669>T$ table 1, 96). Customer satisfaction also has significant effect on customer loyalty at path coefficients 0.256 ( $t$ stats $=2,893>T$ table $=1,96)$, and it partly mediate the relationship between Loyalty Programs and customer loyalty
\end{abstract}

Keywords: Loyalty Program, Customer Satisfaction, Customer Loyalty, Mobile Service.

\section{Introduction}

Indonesia's mobile industry has undergone rapid development and growth over the past decade. Along with the development, the number of mobile customers also experienced a considerable increased. During the year of 2013 - 2017, the number of mobile phone subscribers increased almost twice its fold with a growth of 9.73 percent per year. On the other hand, however, diffusion rate or accumulated percentage of the adoption of new mobile products or services is stagnant. This is an indication that the market has reached its saturation stage. In such situation, high competition among the mobile provider in the industry is inevitable. The services providers experienced unstable sales, cash flow and profit sustainability. Attracting new customers and retaining existing customers are not only difficult but also costly (Kim et al., 2004). Churn rate becomes higher as Zoratti (2012) revealed that the average mobile user switched carriers every 48 months to take advantage of the low cost and benefits of signing a new contract. Matzler et al., (2015), argued that the increasing competition and declining customer loyalty account for the situation.

Keropyan and Gil-Lafuente (2012) posited that in an increasingly intense competition, loyalty program can provide great benefits for mobile providers. The same thing also argued by Dorotic et al., (2012) who argued that the marketing strategy of a company should have shifted from efforts to acquire new buyers to the effort to maintain customer loyalty. Mobile services must utilize existing consumers to increase their profits (Czajkowski and Sobolewski, 2016).

One of the most popular strategies to maintain market share for companies engaged in a service industry is to apply loyalty program (Baran, Strunk, \& Galka, 2008). A number of previous research have studied loyalty programs in various aspects, such as how customers perceive the benefits of the loyalty programs (Bose \& Rao, 2011; Radder et al., 2015), developed a scale to measures the key benefits that the customers perceived when they participate in the loyalty program (Mimouni-Chaabane \& Volle, 2010); Impact of hedonic and utilitarian values on customer satisfaction and behavioral intention (Hanzaee \& Rezaeyeh, 2013); The relationship between the program benefits (Omar et al., 2015), the linkage between the perceived benefits of the retail loyalty programs (Kim et al., 2013; Omar et al., 2015). Nevertheless, there is not researcher focusing their on the influence of customer loyalty programs towards customer satisfaction and loyalty in the mobile telecommunication services sector. This study, therefore, will examine the effect of loyalty program on customers loyalty to mobile services and the role of customer satisfaction in mediating the relationship between loyalty program and customer loyalty.

\section{Literature Review}

Customer loyalty is an essential element for organizational success and profitability. Scholars and practitioners have explored the various benefits of customer loyalty and competitive advantage in every business environment that is very high in competition (Seto-Pamies, 2012; Saleem, Zahra, Ahmad, \& Ismail, 2016). Pan et al., (2012) for example explained how creating and personifying customers helped companies build long-term relationships with mutually beneficial customers. Loyal customers demonstrate engagement and commitment to the company and are not interested in competitor offerings (So et al., 2013). Loyal customers want to pay more, show higher buying intentions and do not want to move to competitors 
(Evanschitzky et al., 2012). Dehghan and Shahin (2011) posited that consumers who demonstrated their loyalty to a service were more likely to re-purchase more and spend more money to buy.

Chi-Chen, Chang, \& Chuang (2016) in their study revealed that to maintain business amidst the competitive environment many companies used defensive strategies. Seto-Pamies (2012) posited that Loyalty program had ability to sustain customers and transformed them into loyalty. It provided incentives to customers to strengthen advanced marketing exchanges with customers and acquired their coordinated and membership-based loyalty (Sandada and Matibiri, 2015).

Previous research also revealed that loyalty programs were instrumental to ensure customers satisfaction and to retain their loyalty (Bahri-Ammari \& Bilgihau, 2017). Satisfied customers are customers who are also members of a loyalty program, and they tend to be more loyal and less sensitive to prices (Omar, Aziz, \& Nazri (2011) posited that customer satisfaction mediate the relationship between loyalty programs and customer loyalty. Other literature further revealed that the loyalty program was the antecedent of customer satisfaction (Soderlund \& Colliander, 2015) and customer satisfaction is the antecedent of customer loyalty (Kandampully, Zhang, \& Bilgihan, 2015). Further argument suggests that customer satisfaction is one of the antecedents of customer loyalty that tends to conform to the emotions and cognition of the customer (Vesel \& Zabkar, 2009) and other factors needed to prevent any customer defection.

\section{Conceptual framework and research hypothesis}

Based on the literature reviews, we can develop the conceptual framework of this study and the research hypothesis. Figure 1 presents the conceptual framework of this study:

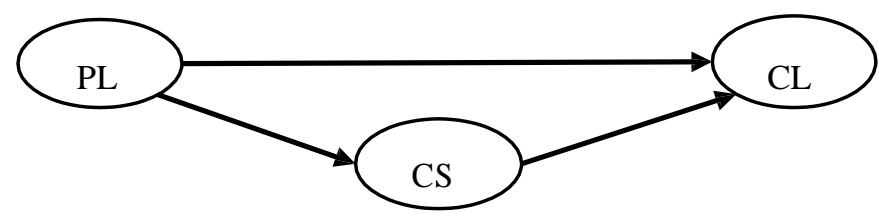

Note: $\mathrm{LP}=$ Loyalty Program, CS = Customer Satisfaction, $\mathrm{CL}=$ Customer Loyalty

Figure 1. Research conceptual framework.

Based on the research conceptual framework, the hypothesis are proposed as the following:

Hypothesis 1 : Perceptions of customer loyalty program benefits positively and significantly directly affect customer loyalty.

Hypothesis 2 : Perception of customer loyalty program benefits positively and significantly affects customer satisfaction.

Hypothesis 3 : Customer satisfaction positively and significantly affect customer loyalty.

Hypothesis 4 : Customer satisfaction mediate the relationship between loyalty program and customer loyalty.

\section{Research Method}

Data was collected from mobile operator customers of in Jambi City using survey method. The questionnaires of loyalty program variable adopted Mimouni- Chaabane and Volle (2010) and customer loyalty variable adopted Zhang and Lu (2014). Both quesionnaires were measured using 5-digit Likert Scale range from $1=$ strongly disagree to $5=$ strongly agree. The customer satisfaction questionnaire adopted Xuanzhang and Feng (2009) and measured using a 5-digit scale ranging from $1=$ very dissatisfied to $5=$ very satisfied. The target population was all customers of mobile service in Jambi city. The samples were chosen using non- probability sampling and the sample size was determined in accordance with Structural Equation Modeling (SEM) requirements, which is Maxsimum Likehood (ML) method by Hair, et al. (1998). The recommended sample size, therefore, was between 100-200. SmartPLS version 3 was applied to test hypothesis, the model fitness and further evaluate the validity and reliability of the research construct.

\section{Result and Discusssion}

This study research applies Partial Least Square (PLS) analysis approach to test the research hypotheses. The empirical results of the research model is represented in Figure 2 below: 


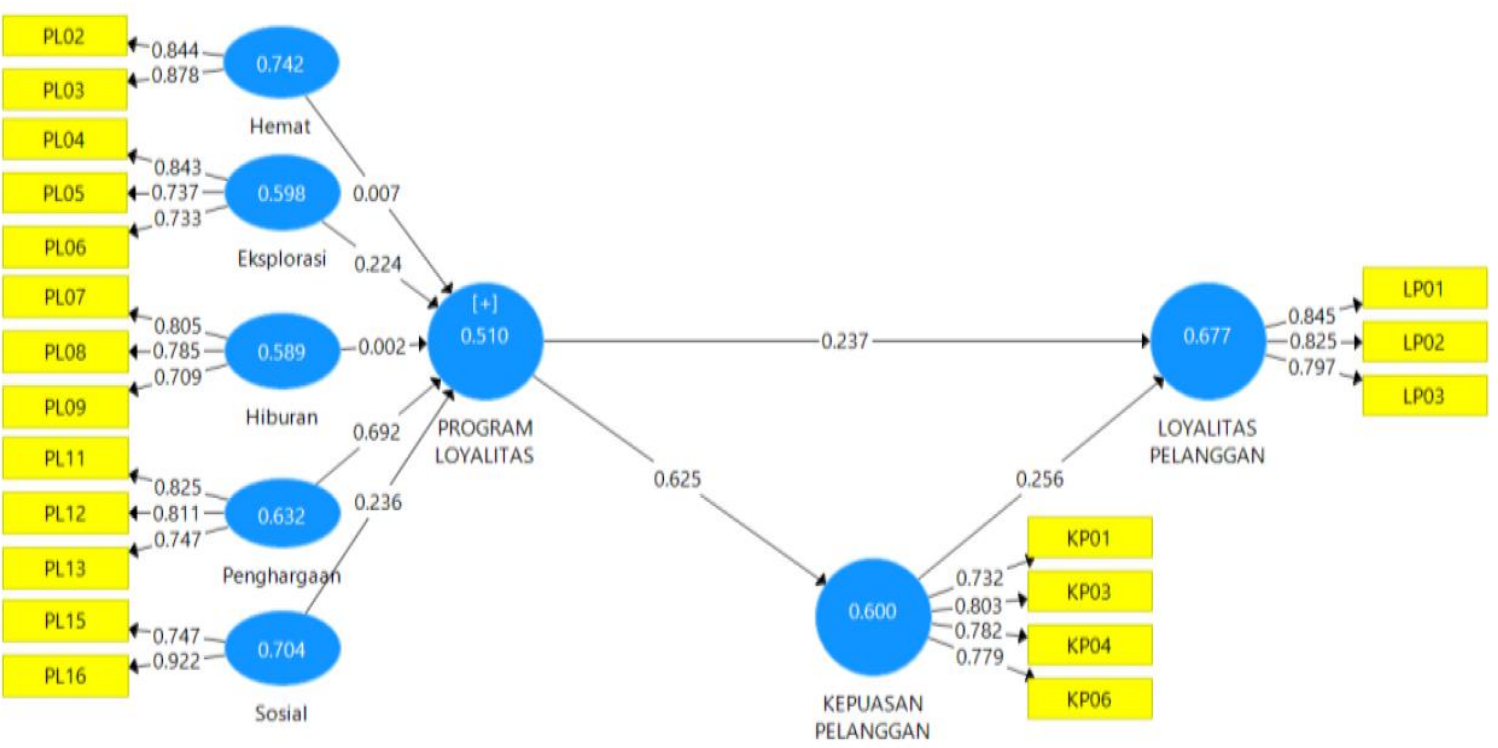

Figure 2. Structural Model

The construct reliability, convergent validity, and discriminant validity test to all constructs indicate sufficient reliability and validity. All composite reliabilities $(\rho)$ were above 0.70 . All average variance extracted (AVE) values were greater than 0.50, and the AVE for each construct was greater than the squared correlation with any other construct, indicating sufficient convergent and discriminant validity.

Table 1 below contains sample mean, $t$-values, $p$ values of each construct. It can be concluded from table 1 below that $\mathrm{H} 1, \mathrm{H} 2, \mathrm{H} 3$ are accepted as their P Values $<0.05$. CS and LP positively and significantly affect $\mathrm{CL}$ and LP also positively and significantly affects influence CL.

Table 1. Path Coefficient

\begin{tabular}{lccc}
\hline \multicolumn{1}{c}{ Hypothesis } & Sample Mean & T Statistics & P Value \\
\hline Customer Satisfacation ->Customer Loyalty & 0,262 & 2,960 & 0,003 \\
\hline Loyalty Program -> Customer Satisfaction & 0,630 & 14,028 & 0,000 \\
\hline Loyalty Program -> Customer Loyalty & 0,234 & 2,710 & 0,007 \\
\hline
\end{tabular}

A follow-up analysis explored the mediating role of customer satisfaction. As can be found in table 2 below, LP and CL Customer Loyalty with CS mediates the relationship between, with CS as a mediating variable was proven by $\mathrm{P}$ value $<0.05$.

Table 2. Indirect Effect

\begin{tabular}{lccc}
\hline \multicolumn{1}{c}{ Variable/Construct } & Sample Mean & T Statistics & P Value \\
\hline $\begin{array}{l}\text { Loyalty Program } \rightarrow \text { Customer Satisfaction } \\
\rightarrow \text { Customer Loyalty }\end{array}$ & 0,165 & 2,840 & 0,005 \\
\hline
\end{tabular}

The mediation testing using VAF method reveals that the direct influence is significant (a) when CS variable was not incorporated into the model. When CS variable is inserted into the model, the indirect effect (b x c) is also found to be significant. The paths $b$ and $\mathrm{c}$ are also significant. Variance Accounted For (VAF) is calculated to determine whether CS play as fully or partially mediator:

$$
\mathrm{VAF}=\frac{\text { Indirect Effect }}{\text { Direct effect }+ \text { Indirect Effect }}=\frac{(0,625 * 0,265) \quad 0,165}{0,237+(0,625 * 0,265)}=0, \overline{0,402}=0,410
$$

Refer to Hair et al. (2013), the value of VAF is $41.0 \%$ which mean the customer satisfaction variables partially mediate the relationship between loyalty program and customer loyalty.

\section{Discussion}

This study makes a contribution to the existing body of knowledge of customer behavior literature by establishing and testing the mediating effect of customer satisfaction in the loyalty program and customer loyalty relationship in the case of Jambi city. There are some previous researchers who studying the relationship between loyalty program and customer loyalty including the mediating role of customer 
satisfaction. However, there is shortages of research on the mediating effect of customer satisfaction on the relationship between loyalty programs and customer loyalty specifically in mobile services.

Our findings support the hypothesis that loyalty program significantly and positively affect customer satisfaction, consistent with findings studies by Martaleni (2017) and Sugiati (2017). Customer satisfaction has also found to be significantly and positively impact on customer loyalty. The same finding is found in many previous research such as Matabiri, 2015; Kang, Alejandro, and Grosa, 2015). By and large, the findings of the current study provide tentative support to the proposition that loyalty programs and customer satisfaction should be recognized as significant antecedents for customer loyalty in the context of mobile service.

The role of customers satisfaction in the relationship between loyalty program and customer loyalty is found to be a partial mediator (quasi mediation), consistent with this research finding in the study by $\mathrm{Al}$ Mansour et al (2015). It means that customer satisfaction does not play importance role in the relationship between loyalty program and customer loyalty. Thus, customer satisfaction does not necessary play important role as a mediating variable between loyalty programs and customer satisfaction

\section{Conclusion}

The study has revealed loyalty program and customer satisfaction both have positive and significant effect on customer loyalty. Loyalty program also has positive and significant influence on customer satisfaction. Customer satisfaction, therefore, play partial mediation in the relationship between loyalty program and customer loyalty.

\section{References}

Bahri-Ammari, N. (2014a) ,The role of Loyalty Program (LP) in establishing brand attachment and word-ofmouth intentions: an empirical investigation in the mobile sector ${ }^{\text {ee }}$, International Journal of Customer Relationship Marketing and Management (IJCRMM), Vol. 5, No. 3, July-September, pp.49-68.

Baran, R., Strunk, D., \& Galka, R. (2008). Principles of Customer Relationship Management. Ohio: Thomson Southern - Western.

Bose, S., \& Rao, V. (2011). Perceived benefits of customer loyalty programs: validating the scale in the Indian context. Management and Marketing Challenges for the Knowledge Society, 6 (4), 543-560.

Chi-Chen Li ,Tin-chang Chang (2016),Shu-Hui ChuangCustomer Satisfaction and Customer Loyalty towards the Green Hote. Based on cases studied in Ken- ding area in Taiwan. Department of Business Administration, Asia University Taichung, Taiwan.

Czajkowski, M. and Sobolewski, M. (2016) „How much do switching costs and local network effects contribute to consumer lock-in in mobile telephony? $?^{\text {ee }}$ Telecommunications Policy, Vol. 40, No. 9, pp.855-869.

Deghan, A. and Sahin, A. (2011). Customer Loyalty Assessment: A Case Study in MADDIRAN, the Distributor of LG Electronics in Iran. Business Management and Strategy. Vol. 2, No. 1: E2.

Dorotic, M., Bijmolt, T. H. A.,\&Verhoef, P.C. (2012). Loyalty programs: Current knowledge and research directions. International Journal of Management Reviews, 14(3), 217-237.

Evanschitzky, H., Ramaseshan, B., Woisetschläger, D.M., Richelsen, V., Blut, M. and Backhaus, C. (2012), "Consequences of customer loyalty to the loyalty program and to the company", Journal of the Academy of Marketing Science, Vol. 40 No. 5, pp. 625-638.

Hair, Joseph, E.J.R Anderson Ralph E, Tathan Ronald L, and Black William C,1998. Multivariate Data Analysis. 5th Edition. New Jersey: Prentice Hall, Inc.

Hanzaee, K. H., \& Rezaeyeh, S. P. (2013). Investigation of the effects of hedonic value and utilitarian value on customer satisfaction and behavioural intentions. African Journal of Business Management, 7(11), 818-825.

Kandampully, J., Zhang, T. and Bilgihan, A. (2015) „Customer loyalty: a review and future directions with a special focus on the hospitality industryee, International Journal of Contemporary and Hospitality Management, Vol. 27, No. 3, pp.379-414.

Keropyan, A. and Gil-Lafuente, A.M. (2012) „Customer loyalty programs to sustain consumer fidelity in mobile telecommunication markete, Expert Systems with Applications, Vol. 39, No. 12, pp.11269-11275.

Kim, M, Park, M \& Jeong, D (2004). The effects of customer satisfaction and switching barrier on customer loyalty in Korean mobile telecommunication services. Telecommunications Policy, 28, 145-159.

Kim, H. Y., Lee, J. Y., Choi, D., Wu, J., \& Johnson, K. K. P (2013). Perceived benefits of retail loyalty programs: their effects on program loyalty and customer loyalty. Journal of Relationship Marketing, 12(2), 95-113. https://doi.org/ 10.1080/ 15332667.2013.794100

Lee, H. S. (2010). Factors influencing customer loyalty of mobile phone service: Empirical evidence from Koreans. Journal of Internet Banking and Commerce, 15(2), 1-14.

Matzler, K., Strobl, A., Thurner, N. and Füller, J. (2015) „Switching experience, customer satisfaction, and switching costs in the ICT industryee, Journal of Service Management, Vol. 26, No. 1, pp.117-136.

Meyer-Waarden, L. (2007) „The effects of loyalty programs on customer lifetime duration and share of

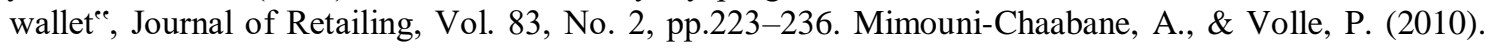


Perceived benefits of loyalty programs: Scale development and implications for relational strategies. Journal of Business Research, 63 (1), 32-37.

Omar, N. A., Ramly, S. M., Alam, S. S., \& Nazri, M. A. (2015). Assessing the effect of Loyalty Program Benefits in Satisfaction-Loyalty Relationship: Evidence from Malaysia. Jurnal Pengurusan, 43, 145-159. https://doi.org/10.17576/pengurusan-2015-43-13 Qualitative Research in Financial Markets, 5(2), 139160. doi: 10.1108/QRFM-11-2011-0028

Pan, Y., Sheng, S. and Xie, F.T. (2012) „Antecedents of customer loyalty: an empirical synthesis and reexamination "e, Journal of Retailing and Consumer Services, Vol. 19, No. 1, pp.150-158.

Radder, L., Eyk, van M., \& Swiegelarr, C. (2015). Levels of customer loyalty and perceptions of loyalty programme benefits: a South Africa retail example. The retail and Marketing Review, 11(1), 92-105.

Saleem, M., Zahra, S., Ahmad, R., \& Ismail, H. (2016). "Predictors of customerloyalty in the Pakistani banking industry: a moderated-mediation study", International Journal of Bank Marketing, 34 (3), 411 430,

Sandada, Maxwell., Matibiri, Bright. (2015). "The Mediating Influence of Passenger Satisfaction on the Relationship between Passenger Loyalty Programmes and Passenger Loyalty. STUDIA UNIVERSITATIS BABEȘ- BOLYAI OECONOMICA, (VOLUME 60, ISSUE 3, 20).

Seto-Pamies, D. (2012). Customer loyalty to service providers: examining the role of service quality, customer satisfaction, and trust. Total Quality Management, 23 (11), 1257-1271.

So, K.K.F., King, C., Sparks, B.A. and Wang, Y. (2013), "The influence of customer brand identification on hotel brand evaluation and loyalty development", International Journal of Hospitality Management, Vol. 34, pp. 31-41.

Söderlund, M. and Colliander, J. (2015) „Loyalty program rewards and their impact on perceived justice, customer satisfaction, and repatronize intentions ${ }^{\text {ee }}$, Journal of Retailing and Consumer Services, Vol. 25, pp.47-57.

Vesel, P., \& Zabkar, V. (2009). Managing customer loyalty through the mediating role of satisfaction in the DIY retail loyalty program. Journal of retailing and customer services, 16, 396-406. Vroom, V. H. (1964). Work and Motivation, NY, Wiley.

Waari, et al., (2018) Loyalty Programs Benefits And Customer Loyalty: The Mediating Role Of Customer Satisfaction. International Journal of Economics, Commerce and Management. Vol. VI, Issue 4.

Xuan Zhang and YuanguanFeng (2009), The Impact of Customer relationship Marketing Tactics on Customer Loyalty - within Sweden Mobile Telecommunication Industry: Master's Dissertation in International Marketing: Halmstad University.

Zhang and $\mathrm{Lu}$ et al. (2014). zhang \& Lu, Gupta, Zhao \&Chen, and Huang. (2014).Understanding the antecedents of customer. Int. J. Mobile Communications, Vol. 12, No. 6, 2014

Zoratti, S. (2012) A Lesson in Loyalty from Mobile Phone Subscribers, CMO.by Adobe, Available at: http://www.cmo.com/articles/2012/9/17/a-lesson-in- loyalty-from-mobile-phonesubscribers.html 